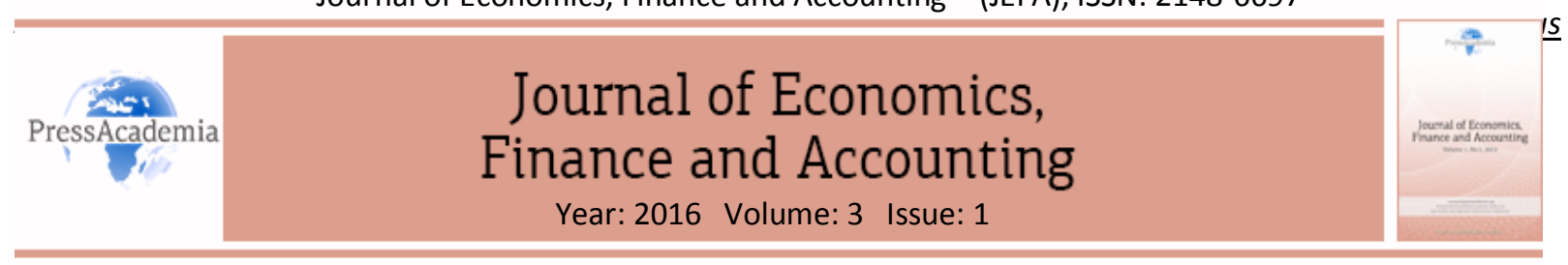

\title{
A PROPOSAL FOR CONSTRUCTING A BOND INDEX ON TURKISH PUBLIC LEASE CERTIFICATES
}

\section{DOI: 10.17261/Pressacademia.2016116536}

\section{Sinan Okumus}

Gedik University.sinan.okumus@gedik.edu.tr

\begin{abstract}
Lease certificate market ha been growing on both government and private sector front in Turkey. Lease certificates are issued as asset based and they distribute rental income as opposed to conventional bonds paying interest to its investors. Investors of the lease certificates face with liquidity risk and high transaction costs due to large bid and ask spreads. Investing in Turkish lease certificates through Exchange Traded Fund can improve the lease certificate market and thus helps increasing the liquidity in the secondary market. The proposed Index (and also the Exchange Traded Fund) will differ from the existing indices by distributing the rental income of the lease certificates. In this paper we tried to set the rules and calculation methodology for Turkish Public Lease Certificates Index such that an Exchange Traded Fund, distributing rental payments will be constructed upon the Index.
\end{abstract}

Keywords: Bond indexing, exchange traded funds, Turkish Lease Certificates, Islamic Finance, Sukuk. JEL Classification: G11, G12, G23

\section{INTRODUCTION}

Global Islamic Finance assets have grown at a compounded annual growth rate (CAGR) of $16.94 \%$ within the period of $2009-2013$ and reached to 1.9 trillion U.S. Dollars in the first half of 2014 according to Islamic Finance and The Real Economy report by KFH Research Ltd. The rapidly growing industry is attracting both the States and the private sector ranging from banks to companies.

Turkey has entered into Islamic Finance industry along with the foundation of the first Islamic Bank in 1985 (Okumus,2014). However, Turkey has not been active in the other areas of Islamic Finance like debt instruments, life and non- life insurance, asset management and brokerage up until recently.

The publication by The General Directorate of Revenue Policies on Taxation of Sukuk (Leasing Certificates) in Turkey indicates that the regulatory framework and tax incentives in between 2010-2012 paved the way for the formation of the Lease Certificates market in Turkey.

Republic of Turkey Prime Ministry Undersecretariat of Treasury (The Treasury) has started issuing Public Lease Certificates denominated in Turkish Lira and U.S. Dollar which are designed to comply with the Islamic Law since 2012. The Treasury aims to diversify the borrowing instruments, attract a broader base of investors and fulfill the investment needs of the Islamic Banks (called as Participation Banks in Turkey) and individuals who are sensitive to interest which is banned by the Islamic Law. Lease certificates being asset based and paying rent instead of interest comply with the tenets of Islamic Bonds which is commonly known as Sukuk.

On the private sector side, Participation Banks started issuing U.S. Dollar denominated lease certificates in 2010 (Uyan,2011) and Turkish Lira denominated lease certificates in 2013 according to Turkey Islamic Finance Report 2014. Participation Banks initially were considering lease certificates as an expensive alternative to their participation accounts (time deposits), however after observing conventional investors were also showing interest to the lease certificates they had become more active in borrowing through lease certificates. Lease certificates have also enabled Participation Banks to extend the duration of their liabilities and improved their 
cash management abilities. According to news on Reuters, other private sector companies are also on their way to borrow from the financial markets via Lease Certificates.

The investors of the lease certificates are Participation Banks, individuals with interest sensitiveness, mutual and pension funds which can only invest in interest free products, conventional mutual and retirement funds and foreign investors with interest sensitiveness, trusts and corporates which are also sensitive to interest.

Borsa Istanbul and Turkish Treasury data indicate that total amount of Turkish Lira denominated lease certificates reached to 6.5 billion TL, a mere $1.5 \%$ of the total Turkish Lira based debt. The U.S. Dollar denominated lease certificate issues totaled 2.75 billion U.S. Dollar, consisting $3.15 \%$ of the total foreign debt.

As it is indicated above the lease certificate market is quite new and showing promise for the growth in the future. However, there are some obstacles preventing the growth of the lease certificate market.

The biggest obstacle is the lack of enough liquidity in the secondary market trading. The investors should be able to liquidate the lease certificates with the current market prices when they needed to. Such that a liquid secondary market for lease certificates is crucial for the upcoming lease certificate offerings.

Some issuers of the lease certificates recently started to address the problem by quoting double sided prices in line with current market prices for their issues in order to provide liquidity comfort for the investors.

On the other hand individual and corporate investors with interest sensitiveness are thought to have a better understanding of the lease certificates within the upcoming years.

The growth of the lease certificate market is important for the Participation Banks and the Islamic pension / mutual funds as well as Istanbul to become regional finance center with a developed Islamic Finance industry.

Another capital market investment vehicle to contribute the growth of the lease certificate market is the Exchange Traded Funds (ETFs).

ETFs combine the benefits of the equities and the mutual funds. ETFs invest into a portfolio by emulating an Index. The index can be comprised of bonds, equities, commodities or other types of assets. ETFs are open ended funds which allow the creation and redemption of the fund shares.

Global ETF industry reached to around 2.6 trillion U.S. Dollars as of July 2014. Pension funds, government agencies, private banks and individual investors have been investing through ETFs according to Investor Guide to ETFs by iShares.

Investing in Turkish lease certificates through Exchange Traded Funds can improve the lease certificate market and thus helps increasing the liquidity in the secondary market. The investors obtain the benefits of investing in a basket of lease certificates and avoid of the liquidity problems of investing directly into lease certificates.

In this paper we tried to set the rules and calculation methodology for Turkish Public Lease Certificates Index such that an ETF distributing rental payment will be constructed upon the Index.

\section{BOND INDEXATION IN TURKEY}

The first bond indices have been calculated and published by Istanbul Stock Exchange (currently named as Borsa Istanbul) since 1996 (Kona,1997). Today several companies and institutions such as FTSE, iBoxx, Borsa Istanbul and Turkish Institutional Investors' Association (TKYD) calculate and publish Turkish Lira based bond indices. According to Capital Markets Board of Turkey (SPK) data, there are two TL based bond index tracker Exchange Trading Funds. One is founded in 2007 by Finansbank and tracking FTSE Turkish Lira Government Bond Index. The other one is founded by Is Investment in 2008 and was tracking iBoxx Turkey Benchmark Bond Index. The fund started tracking Is Investment Long Term Bond Index, calculated by Milenyum Ltd. after 18.02.2013 according to the company website.

\section{FTSE TURKISH GOVERNMENT BOND INDEX}

The Index is created and calculated by FTSE International Limited as part of the FTSE Global Bond Index Series. According to the index factsheet, the index was launched in $26^{\text {th }}$ June 2006 with a base date of $31^{\text {th }}$ December 
2004. The index is constructed from domestic bonds with a minimum notional amount outstanding of one Billion Turkish Lira and includes both straight bullet bonds and zero coupon bonds. FTSE calculates both price and total return indices by using prices of Borsa Istanbul. The index is calculated real-time from 06:30-14:00 GMT \& Endof-Day. The settlement is $T+0$ in the morning and $T+1$ in the afternoon. The index is rebalanced monthly at the end of the last business day of the month, with bonds removed when their maturities fall below 6 months. New issues are included once a month after the close of the last business day of the month. The index is managed according to a publicly available set of rules and is designed to act as the foundation for ETFs, Structured products and Index tracking funds.

FTSE Istanbul Bond ETF (FBIST) is founded by Finansbank A.S.in $24^{\text {th }}$ October 2007 and tracking FTSE Turkish Lira Government Bond Index. According to the fund web site, The FBIST provides exposure to a basket of Turkish fixed income securities with a single transaction.

According to FBIST manager Ince M.(personal communication October 22, 2014), the ETF is all-bonds fund meaning the fund invests to all bullet and zero coupon Government bonds with a minimum notional amount outstanding of one Billion Turkish Lira. The fund reinvests equally the coupon proceeds. The bonds with less than 6 months to maturity are removed with the rebalanced at the end of the last business day of the month. The bond reissues do not change the weightings of the bonds. If there is no market transaction and thus no market price for a certain bond, the valuation is made through the last traded price plus the accrued interest.

\section{IS INVESTMENT LONG TERM BOND INDEX}

The Index is calculated and published by Milenyum Ltd. According to the Is Investment Long Term Bond Index ETF prospectus, the index includes eight Turkish Lira denominated straight bullet or/and fixed coupon Government Bonds with a minimum notional amount outstanding of one Billion Turkish Lira. Each bond is equally weighted and each weight is $12.50 \%$. The bonds with more than 180 days to maturity will be included. The bonds are required to be listed with the Borsa Istanbul Exchange. Eight bonds with the longest maturity will be included within the index amongst the bonds comply with the index criteria. If the eligible number of bonds for the Index is less than eight, the weighting will be equally distributed amongst the remained bonds.

The Index will be revised in each February, May, August and November. Revision is made on the $2^{\text {nd }}$ Friday of the month and the application to the index on the $3^{\text {rd }}$ Friday of the month. The coupon proceeds are assumed to be reinvested in the Index. The index is calculated continuously in every 15 seconds by using last prices of Borsa Istanbul during the exchange hours. In the lack of the daily basis market transaction the valuation is made through the last traded price plus the accrued interest.

\section{CONTRUCTING AN INDEX FOR THE TURKISH PUBLIC LEASE CERTIFICATES}

As pointed above, we aim to lay the ground for an ETF investing in to the Turkish Lira based public lease certificates. The ETFs provide investors to buy or sell a basket of investment vehicles in a simpler way. In this case ETF investors would be investing into a portfolio of public lease certificates.

Lease Certificates are designed to provide investor interest free fixed rental returns in specific periods. Given that, ETF and the underlining Index would also distribute the coupon proceeds to its investor instead of reinvesting within the fund.

In this section we try to construct a lease certificates Index that can be tracked by ETFs.

\subsection{Bond Indexing Principles}

There are various aspects and difficulties of constructing a bond index due to the nature of the bond markets. A joint commission of EFFAS (The European Federation of Financial Analyst Societies) and ISMA (International Securities Market Association) set out standardized rules of constructing bond indices (Brown, 1994). They have proposed a set of rules for indices in order to answer to different aspects and obstacles of constructing bond indices in various markets. We will implement the index construction rules along with the local market conditions and needs in constructing an Index for the Turkish Public Lease Certificates.

Basic principles of index construction process are (Shariffmuddin and Chong, 2013); 


\section{Comprehensive and Accurate}

- $\quad$ An index should reflect the performances of new investments and existing holdings under a realistic representation of market condition.

- This also provides a fair representation of available investment opportunities.

\section{Transparent}

- Index methodology and rules are published and made known to users.

- $\quad$ Along with index levels, daily index statistics are available to users.

Replicable

- Market participants should be able to replicate the indices for performance measurements.

Stable

- The index should allow market participants to derive a realistic baseline strategy.

- $\quad$ Changes of index compositions should occur infrequently unless an index breaches the prespecified ground rules which are both understandable and predictable.

- Preferably, changes should not lead to investors executing significant transactions to keep pace with the index levels.

\section{Contains accessible characteristics and information}

- $\quad$ Price, coupon rate and risk statistics are all available and accessible for investors.

- Historical index and price levels are available for time series analysis.

Investable

- $\quad$ Bonds are investable and do not contain barriers of entry.

- For example, an international index should not contain bonds that discourage foreign ownership.

\subsection{Index Construction}

Our aim in this study is to construct an Index, based on Turkish Lira denominated public lease certificates such that Exchange Traded Funds can emulate the Index. A typical investor who would like to invest in lease certificates but do not want to take liquidity risk or high transaction costs due to large bid-ask spreads can invest in ETF's. The Index (and also the ETF's) will differ from the existing indices by distributing the rental income of the lease certificates. Rental income distribution is considered crucial for individual investors of lease certificates.

\section{Types of Bond Index}

Bond index types categorized as All-bond index, Tracker index and Bellwether index. All-bond indices include all available bonds in the sector both liquid and illiquid which fit into the basic bond rules. As for a Tracker index, several market related conditions like market value, liquidity and rating would be applied to the bonds to be included in the index. A Bellwether index on the other hand includes only the most liquid benchmark issues (Brown, 1994, p.19).

The proposed public lease certificate index would be an All-bond index since it will include all issues regardless of issue size, liquidity and rating. According to Borsa Istanbul data there are currently four public lease certificate issues. The Treasury issues lease certificates with 2 years maturity, fixed rental income with coupons payable in every 6 months and the nominal issue size greater than one billion Turkish Lira.

\section{Portfolio Emulation}

The index should reflect the changes in its underlying portfolio. When there would be a change in the prices of the constituting bonds, the index should observe same proportion of change. The index computation is based on arithmetic calculation. The arithmetic calculations are chain-linked meaning that the index value at time $(t)$ is calculated by multiplying the index value in time $(t-1)$ by the aggregated one day percentage change in the value of the underlying bonds (Pawaskar, Roy and Darbha, 2002). 


\section{Bond Weightings}

Mainly in bond indexing, each individual bond's weighting is calculated either with the issue size or with market value such that higher outstanding amount of an issue implies higher liquidity within the secondary market (Kilimci, Er and Çerçil, 2014). Equal weighting is also a method of defining bond weighting in some indices as it has been the case for Is Investment Long Term Bond Index.

We will use outstanding nominal value weighting in indexing public lease certificates. Reissues of the certificates will not change the weighting.

\section{Bond Specifications}

The proposed index will include all Turkish Lira denominated public lease certificates traded in Borsa Istanbul regardless of issue size, liquidity or rating. The Treasury currently issues certificates with fixed coupon payments based on lease contracts. If the Treasury issues Floating Rate Certificates in the future, they should be excluded from the index as recommended by EFFAS (Brown, 1994, p. 59).

The public lease certificates are strippable meaning the coupon payments and redemption payments can be traded separately. In indexing we would disregard striping and treat the certificates as one cash flow.

Turkish Treasury issues lease certificates with 2 years maturity since launching the first issue in 2012. The Treasury rolls over the certificates upon the redemption of the current issues.

\section{Maturity Sub-Groups}

Typically, different investor groups have different investment perspectives in bond investing. Investors like pension funds or insurance companies prefer to invest in to long term bonds. So their benchmark index should reflect the long term bond portfolio. Accordingly, sub-indices should be calculated in addition to the total index calculation. EFFAS suggested maturity sub-groups of 1-3 years, 3-5 years, 5-7 years, 7-10 years, over 10 years and irredeemable securities (Brown, 1994, p. 36). As in the case of Malaysia, maturity sub-groups are designed as bonds with residual maturity of 0.25 to 1 year, 1-3 years, 3-7 years and over 7 years (Shariffmuddin and Chong, 2013, p.4).

As indicated above, our aim is to construct an index which will emulate the portfolio of Exchange Traded Funds investing in to public lease certificates. The proposed ETF will invest in all certificates with different maturities. Such that we do not propose any maturity sub-groups at this point.

\section{Treatment of the Coupon Payments}

The proposed ETF product is designed to eliminate investors' liquidity and high transaction cost risks in investing public lease certificates. A typical individual investor of public lease certificates could be identified as someone looking for interest free products and periodical rental income. Given that the proposed ETF should also distribute periodical rental income in order to fulfill the needs of the investors. Once the public lease certificates in the portfolio of ETF make coupon payment then the ETF will also make the same payment to its investors same day or the next day.

Thus the proposed index itself should reflect the coupon payments. We will calculate the clean price index (calculated as using clean prices of bonds without accrued rental income), gross price index (calculated as using dirty prices of bonds) and total return index (calculated as using the clean price plus accrued rental income and coupon payments).

Since the ETF will deliver coupon payments to its investors ETF will take gross price index as benchmark index. However clean price and total return indices will be also calculated for the investors to track performance of the ETF.

\section{Pricing and Settlement Date}

The indices will be calculated continuously by using last prices of Borsa Istanbul during the exchange hours. In the lack of the daily basis market transaction, the valuation is made through the last traded price plus the 
accrued rental income. The settlement will be $T+0$ in the morning and $T+1$ in the afternoon in line with the Borsa Istanbul settlement date.

\section{Portfolio Rebalancing}

Index portfolio rebalancing means inclusion, exclusion and re-allocation of the bond constituents (Shariffmuddin and Chong, 2013, p.5). There is not a common practice of portfolio rebalancing frequency when we review current indices.

As for the Turkish market, FTSE Turkish Government Bond index is rebalanced monthly but Is Investment Long Term Bond Index is rebalanced four times in a year.

The proposed indices will be rebalanced daily. New issues will be included on the first date of trading at Borsa Istanbul. The certificates in the portfolio will be removed when they mature and the proceeds will be reinvested.

\section{INDEX CALCULATION FORMULAE}

Indices will be calculated continuously during the Borsa Istanbul bond trading sessions.

We use the following notation in calculations mainly in line with EFFAS (Brown, 1994, pp. 72-80).

$\mathrm{P} \quad$ : Clean price of the certificate (without accrued rent)

$\mathrm{P}_{i, t} \quad$ : Clean price of the $i$ th certificate at time $t$

AR : Accrued rental income

$\mathrm{N} \quad$ : Nominal value of amount outstanding

$\mathrm{Y} \quad$ : Redemption yield to maturity date

L $\quad$ : Life to maturity date

D : Duration

$\mathrm{X} \quad$ : Convexity

C : Coupon rate as percent

$\mathrm{G}_{i, t} \quad$ : Value of any coupon payment received from the ith certificate for settlement at time $t$ or since time $(t-$

1)

$\mathrm{R} \quad$ : Redemption price of the certificate

\section{Clean Price Index (PI)}

$$
\begin{aligned}
& P I_{0}=100 \\
& P I_{t}=P I_{t-1} \times \frac{\sum_{i} P_{i, t} \times N_{i, t-1}}{\sum_{i} P_{i, t-1} X N_{i, t-1}}
\end{aligned}
$$

\section{Gross Price Index (GI)}

The accrued rent income $(A R I)$ in the index is:

$$
A R I_{t}=\frac{\sum_{i} A R_{i, t} \times N_{i, t-1}}{\sum_{i} P_{i, t} X N_{i, t-1}}
$$

Thus the gross price index $(G I)$ is:

$$
G I_{t}=P I_{t} \times\left(1+A R I_{t}\right)
$$

\section{Total Price Index (TR)}

$$
\begin{aligned}
& T R_{0}=100 \\
& T R_{t}=T R_{t-1} \times \frac{\sum_{i}\left(P_{i, t}+A R_{i, t}+G_{i, t}\right) x N_{i, t-1}}{\sum_{i}\left(P_{i, t-1}+A R_{i, t-1}\right) x N_{i, t-1}}
\end{aligned}
$$




\section{Average Coupon (CO)}

$$
C O_{t}=\frac{\sum_{i} C_{i, t} x N_{i, t}}{\sum_{i} N_{i, t}}
$$

\section{Average Life (LF)}

$$
L F_{t}=\frac{\sum_{i} L_{i, t} x N_{i, t}}{\sum_{i} N_{i, t}}
$$

\section{Average Duration (DU)}

$$
D U_{t}=\frac{\sum_{i} D_{i, t} x\left(P_{i, t}+A R_{i t}\right) x N_{i, t}}{\sum_{i}\left(P_{i, t}+A R_{i, t}\right) x N_{i, t}}
$$

\section{Average Convexity $(C X)$}

$$
C X_{t}=\frac{\sum_{i} X_{i, t} x\left(P_{i, t}+A R_{i t}\right) x N_{i, t}}{\sum_{i}\left(P_{i, t}+A R_{i, t}\right) x N_{i, t}}
$$

\section{Average Current Yield (CY)}

$$
C Y_{t}=100 \times \frac{\sum_{i} C_{i, t} x N_{i, t}}{\sum_{i} P_{i, t} \times N_{i, t}}
$$

\section{CONCLUSIONS}

In this paper we tried to construct an index based on Turkish Public Lease Certificates such that it will lead to the creation of Exchange Traded Funds benchmarking the proposed index. The proposed ETFs will deliver rental income to the investors when the underlying certificates make coupon payments. The very basic purpose of such ETFs is to eliminate the liquidity risk and high transaction costs for the investors of these lease certificates. The same index methodology can be applied to the private sector lease certificates issues as well.

\section{REFERENCES}

Bernardo Vizcaino, "Dogus Group Approved to Issue Turkey’s First Corporate Sukuk”, Reuters, Available at: http://www.reuters.com/article/2014/08/28/turkey-sukuk-idUSL5N0QWODM20140828 (accessed 28 October 2014).

“Borsa İstanbul İşlem Gören Borçlanma Araçlarına illişkin Veriler”, Available at: http://www.borsaistanbul.com/veriler/verileralt/borclanmaaraclari-piyasasi-verileri/piyasa-verileri (accessed 28 October 2014).

Brown P.J. (1994), “Constructing \& Calculating Bond Indices, A Guide to the EFFAS Standardized Rules,” p.4., Probus Publishing Company.

Capital Markets Board of Turkey, "Monthly Statistics Bulletin, August 2014", Available at:

http://www.spk.gov.tr/apps/aylikbulten/index.aspx?submenuheader=0 (accessed 16 November 2014).

FTSE International Limited, "FTSE Turkish Lira Government Bond Index Factsheet", Available at: http://www.ftse.com/Analytics/FactSheets/Home/DownloadSinglelssue?issueName=TRGOVTOP (accessed 16 November 2014).

FTSE International Limited, "Ground Rules for The Management of The FTSE Global Bonds Index Series", Available at: http://www.ftse.com/products/downloads/FTSE Global Bond Index Series.pdf (accessed 16 November 2014).

FTSE Istanbul Bond ETF, “FBIST Exchange Traded Fund” Available at: http://www.fbist.com.tr/page/fbist-exchange-traded-fund (accessed 4 January 2015).

Gursel K. (1997), “A Suggestion for a Bond Index". ISE (Istanbul Stock Exchange) Review ISSN 1301-1642 Volume:1 No:2, April/May/June 1997, p.23.

"Is Investment Long Term Bond Index Exchange Traded Fund Prospectus", pp.2-3, Available at: http://www.isyatirim.com.tr/EskiSite/spk/ISUVTtipi Izahname.pdf (accessed 9 January 2015).

İ̧ Yatırım Menkul Değerler A.Ş., "Iş Yatııım Uzun Vadeli Tahvil Endeksi B Tipi Borsa Yatırım Fonu”, Available at: http://www.isyatirim.com.tr/Fonlar/ISUVT.aspx (accessed 16 November 2014). 
iShares by Blackrock, "Investor Guide to ETFs", p.3., Available at: https://www.ishares.com/uk/individual/en/literature/brochure/investorguide-to-etfs-en-gb-rc-brochure.pdf?siteEntryPassthrough=true (accessed 14 November 2014).

KFH Research Ltd., "Islamic Finance and the Real Economy", p.3., Global Islamic Finance Forum, 2014

Kilimci E., Er H., Çerçil I. (2014), "Devlet iç Borçlanma Senetleri İkincil Piyasa Likiditesini Etkileyen Faktörler”, p.5.,Available at: http://www.tcmb.gov.tr/wps/wcm/connect/13996761-1cd4-4695-aaad-66f5423b6299/EN1419.pdf?MOD=AJPERES\&CACHEID=139967611cd4-4695-aaad-66f5423b6299 (accessed 4 June 2015).

Okumus, S. (2014), İslami Sigorta (Takaful) Türkiye Uygulaması, p.20. Türkmen Yayınevi.

Pawaskar V., Roy S.D., Darbha G. (2002), “The NSE- Government Securities Index: Issues in Construction”, p.5., Available at: http://www.nseindia.com\%2Fcontent\%2Fdebt\%2Fgsec paper.pdf\&ei=zVIsVaXQOciMsAHf14OoAg\&usg=AFQjCNEBIROE3VHuH1a3HE-YIk7C $\overline{6-w t O g}$ (accessed 1 June 2015)

Republic of Turkey Prime Ministry Undersecretariat of Treasury, "Lease Certificate Investor Guide",p.3., $\quad$ Available at: https://www.hazine.gov.tr/File/?path=ROOT/Documents/General\%20Content/Lease20Certificates20Guideline.pdf (accessed 27 October 2014).

Republic of Turkey Prime Ministry Undersecretariat of Treasury, "Net Public Debt" Available at: http://www.treasury.gov.tr/default.aspx?nsw=EilDPQez15w=-SgKWD+pQltw=\&mid=693\&cid=12\&nm=764 (accessed 28 October 2014).

Sharifmuddin B.N. , Chong J. (2013), "Construction Rules and Calculation Methodology for TR BPAM Ringgit Bond Index", p.2., Available at: http://www.bpam.com.my/fileDownload.asp?File=/Stream/docs/\&Name=Methodology.pdf\&Size= (accessed 27 September 2014).

“Taxation of Sukuk (Leasing Certificates) in Turkey”, Available at: http://www.gep.gov.tr/tmp/ Gep4.pdf (accessed 28 October 2014).

Thomson Reuters, Islamic Research and Training Institute, General Council For Islamic Banks and Financial Institutions, "Turkey Islamic Finance Report 2014: Fundamentals and Promise of The Growth", p.70., Available at:

http://www.irti.org/English/Research/Documents/Report-5.pdf (accessed 28 October 2014).

Uyan, U. (2011), “Faizsiz Bankacılık ve Günümüz Bankacılık Uygulamaları”, i̇stanbul iktisatçılar Derneği, Available at: www.ikder.org/sempozyum/Sunumlar4/U.Uyan..ppt (accessed 28 October 2014). 